\title{
Durability Enhancement Of SCC With Waste Glass Powder
}

\author{
Ana Mafalda Matos ${ }^{a *}$, Telma Ramos ${ }^{b}$, Sandra Nunes ${ }^{b, c}$, Joana Sousa-Coutinho ${ }^{a, b, c}$ \\ ${ }^{a}$ Laboratory for Testing Building Materials - LEMC, Department of Civil Engineering, \\ Faculty of Engineering - FEUP, University of Porto, Porto, Portugal. \\ ${ }^{b}$ Laboratory for the Concrete Technology and Structural-LABEST, Department of Civil Engineering, \\ Faculty of Engineering - FEUP, University of Porto, Porto, Portugal. \\ ${ }^{c}$ Department of Civil Engineering, Faculty of Engineering - FEUP, University of Porto, Porto, Portugal.
}

Received: May 19, 2015; Revised: September 16, 2015; Accepted: November 20, 2015

Self compacting concrete (SCC) requires a large quantity of fine materials compared to common concrete. In this work waste glass powder was used to replace (50\%) of filler required. Two types of SCC were manufactured, a control SCC type (CTL) using cement and limestone filler and another with glass powder replacing $50 \%$ of the filler. Mechanical and durability properties, namely, compressive strength, resistivity, chloride ion penetration, carbonation, capillary water absorption and oxygen permeability were assessed on both SCC types. It could be concluded that waste glass powder can be used successfully in SCC improving chloride penetration and water absorption by capillarity and maintaining strength levels. The potential risk of alkali-silica observed on mortar was mitigated when incorporating glass powder.

Keywords: glass powder, SCC, durability, mechanical performance.

\section{Introduction}

Concrete for the $21^{\text {st }}$ century will have to be more durable, easier to apply, more predictable and greener. At the same time it will have to be more cost competitive ${ }^{1}$. A solution to achieve durability of concrete structures, independent of the quality of construction work, is the employment of Self-compacting concrete (SCC) that can be compacted into every corner of a formwork, purely through its own weight and without the need of vibrating compaction ${ }^{2}$

Interest on SCC technology among constructors and in the construction industry in several countries has been growing in the last years. This interest is due to the ease of placing SCC in heavily reinforced areas difficult to access, to the reduced effort in accomplishing some of the casting tasks and also to the significant reduction of the construction period. This technology will, along with the mentioned advantages, lead to a considerable reduction of the acoustic noise levels as well as the use of secondary raw materials ${ }^{3}$.

In particular, for powder type self-compacting concrete production, a high-volume of very fine material is necessary in order to ensure filling ability, passing ability and segregation resistance of $\mathrm{SCC}^{4,5}$. The use of filling materials and mineral additions as cement replacement materials in concrete will tend to fulfill expectations for improved sustainability in the construction industry. Thus, a lot of work has been carried out on the outcome of mineral additions on the properties of SCC. These studies show the advantage of using mineral additions in SCC, such as improved workability with reduced cement

*e-mail: anamatos@fe.up.pt content ${ }^{6,7}$. Since cement is the most expensive component of concrete, reducing cement content is an economical solution. Moreover, mineral additions can improve particle packing and decrease permeability of concrete. Therefore, durability of concrete is also enhanced ${ }^{8}$. Limestone powder and industrial by-products materials such as fly ash and granulated blast furnace slag are generally used as mineral additions in $\mathrm{SCC}^{9,10,11,12}$. Thereby, the workability of SCC is improved and the consumption of by-products or waste materials is increased. Besides economic benefits, this use of by-products or waste materials in concrete reduces the environmental burden in construction.

Many other industrial wastes, not used yet, can be successfully used in SCC, such as waste glass. The percentages of the main constituents of different types of glass are similar, except for $\mathrm{Al}_{2} \mathrm{O}_{3}$ and $\mathrm{CaO}^{13}$. The typical glass composition for soda lime glass is approximately $70 \%$ of silica, $13-17 \% \mathrm{Na} 2 \mathrm{O}$ and $10 \% \mathrm{CaO}^{13}$. In fact, glass can be considered a pozzolanic-cementitious material according to the chemical requirements in ASTM C $618^{14}$ if the alkali content is disregarded. Indeed high alkali content of glass is a typical concern for its use in concrete ${ }^{15,16,17,18}$.

The potential use of finely ground waste glass as a pozzolanic material, focusing on strength development and alkali-silica reactivity has been successfully investigated ${ }^{13,16,17,18,19}$. Fine glass powder showed potential to improve some durability related properties of concrete. When used as a cement replacement material, fine glass powder besides reducing deleterious expansion due to alkali-silica reaction as stated, decreased both sorptivity 
and moisture diffusion coefficient ${ }^{16}$. Resistance to chloride transport is also improved by the use of this addition, indicating some amount of pore refinement ${ }^{13,20}$.

The aim of the present paper is to explore feasibility of using waste glass powder in SCC. Glass powder was used as partial replacement for limestone filler. Subsequently, two SCC types, one with 50\% limestone filler replacement with waste glass powder (BGP SCC) and the other with no waste glass powder (CTL SCC) were produced. Investigation in terms of mechanical and durability properties, namely, compressive strength, resistivity, chloride ion penetration, carbonation, capillary water absorption and oxygen permeability was carried out and results were compared. The potential risk of alkali-silica reaction considering the use of this type of glass powder was monitored in accordance with the accelerated mortar bar test.

\section{Experimental program}

\subsection{Materials}

Concrete types were produced using binder including Portland cement (CEM I 42.5 R), limestone filler (LF) and waste glass powder (BGP). Physical and chemical characteristics of each material can be observed in Table 1, as well as particle size distribution in Figure 1. A polycarboxylate type superplasticizer of specific gravity of $1.05 \%$ and $18.5 \%$ solid content was used.

Crushed calcareous aggregate $(1-12.5 \mathrm{~mm})$, siliceous natural fine sand (sand 1) and a natural coarse sand (sand 2) were used, see Figure 2. Specific gravity of coarse aggregate, sand 1 and sand 2 were 2.61, 2.60 and 2.62, and absorption values $1.29 \%, 0.68 \%$ and $0.51 \%$, respectively.

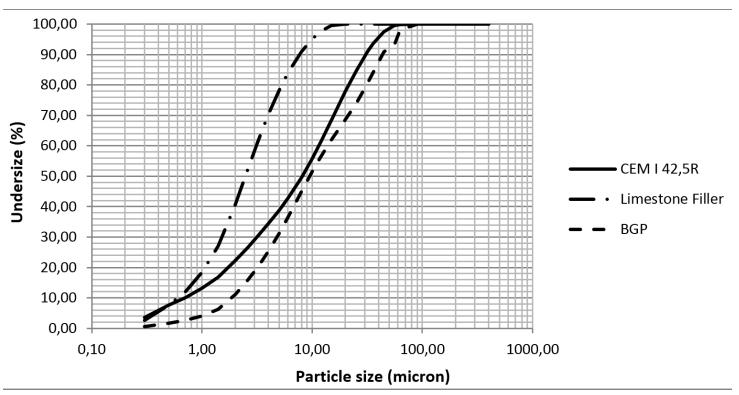

Figure 1. Particle size distribution of cement, glass powder and limestone filler.

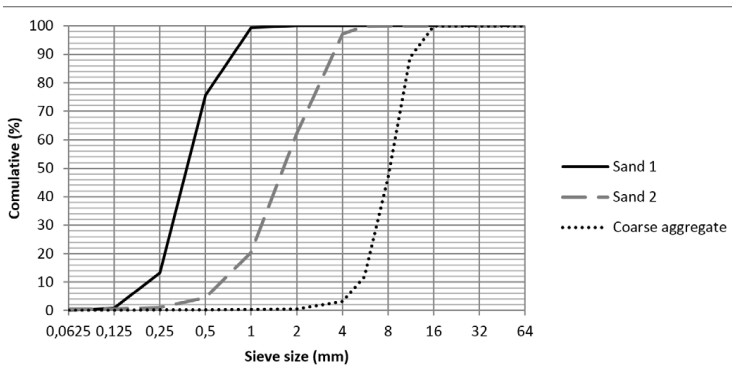

Figure 2. Grading of aggregates.

\subsection{Alkali silica reaction (ASR)}

The potential risk of alkali-silica reaction in concrete was monitored in accordance with the accelerated mortar bar test following ASTM $1567^{21}$, where two mortar prisms with $25 \times 25 \times 250 \mathrm{~mm}$ were produced for each mortar type.

When following the procedure in ASTM, two minor modifications were performed. Instead of using the ASTM required cement: aggregate: water ratio $1: 2.25: 0.47$, the ratio considered in NP EN 196-1 $1^{22}, 1: 3: 0.5$, was used. Also, particle size distribution of (reactive) aggregates shown in Table 2 is required in ASTM C 1567, but the one used (CEN sand) was grading considered in NP EN 196-1, also shown in Table 2. CEN sand used was found to be reactive. Two mortar types were produced: a control mix with $100 \%$ cement (CTL mortar) and a mix with $10 \%$ BGP as cement replacement (10\%BGP mortar). ASTM C 1567 was followed for the remaining procedure. Therefore, immediately after casting, the moulds were covered and demoulded $24 \mathrm{~h}$ later. Afterwards, the specimens were preconditioned for a further $24 \mathrm{~h}$ in water at $80^{\circ} \mathrm{C}$. The lengths of these mortar specimens after immersion in hot water, measured along the 4 faces of each specimen, were then taken as the initial readings $\left(\mathrm{L}_{0}\right)$. The mortar specimens were then transferred to a $1 \mathrm{~N} \mathrm{NaOH}$ solution maintained at $80{ }^{\circ} \mathrm{C}$ and periodically measured for 14 days. Expansion of mortar specimens due to ASR can be seen in Figure 3.

Table 1. Chemical and physical properties of cement, waste glass powder (BGP) and limestone filler (LF).

\begin{tabular}{|c|c|c|c|}
\hline \multicolumn{4}{|c|}{ Chemical properties } \\
\hline & CEM I 42.5 R & BGP & $\mathbf{L F}$ \\
\hline LOI & 2,61 & 0,69 & \\
\hline Insoluble residue & 1,33 & & \\
\hline $\mathrm{SiO}_{2}$ & 20,36 & 72,69 & \\
\hline $\mathrm{Al}_{2} \mathrm{O}_{3}$ & 5,1 & 0,67 & \\
\hline $\mathrm{Fe}_{2} \mathrm{O}_{3}$ & 3,12 & 0,47 & 0.02 \\
\hline $\mathrm{CaO}$ & 62,72 & 8,72 & 99 \\
\hline $\mathrm{MgO}$ & 1,81 & 3,70 & 0.3 \\
\hline $\mathrm{Na}_{2} \mathrm{O}$ & & 12,22 & \\
\hline $\mathrm{K}_{2} \mathrm{O}$ & & 0,21 & \\
\hline $\mathrm{TiO}_{2}$ & & $<0,04$ & \\
\hline $\mathrm{MnO}$ & & $<0,02$ & \\
\hline $\mathrm{P}_{2} \mathrm{O}_{5}$ & & $<0,03$ & \\
\hline $\mathrm{SO}_{3}$ & 3,44 & 1,30 & $<0.05$ \\
\hline $\mathrm{Cl}$ & 0,012 & & $<0.001$ \\
\hline Free lime & 1,62 & & \\
\hline Pozolanicity & & Positive & \\
\hline \multicolumn{4}{|c|}{ Physical properties } \\
\hline $\begin{array}{l}\text { Specific gravity } \\
\left(\mathrm{g} / \mathrm{cm}^{3}\right)\end{array}$ & 3.16 & 2.53 & \\
\hline Blaine $\left(\mathrm{cm}^{2} / \mathrm{g}\right)$ & 4249 & 4954 & \\
\hline $\begin{array}{l}\text { Setting time } \\
\text { initial/ final } \\
\text { (h:min) }\end{array}$ & $2 \mathrm{~h} 30 / 4 \mathrm{~h} 00$ & $\begin{array}{l}{ }^{\mathrm{a}} 10 \% \text { BGP } \\
2 \mathrm{~h} 35 / 3 \mathrm{~h} 45 \\
{ }^{\mathrm{b}} 20 \% \text { BGP } \\
2 \mathrm{~h} 50 / 4 \mathrm{~h} 30\end{array}$ & \\
\hline Soundness (mm) & 1.0 & $\begin{array}{l}\text { a } 10 \% \text { BGP } 1.5 \\
\text { b } 20 \% \text { BGP } 0.5\end{array}$ & \\
\hline
\end{tabular}

a Paste with $10 \%$ cement replacement by glass powder. ${ }^{\text {b }}$ Paste with $20 \%$ cement replacement by glass powder. 


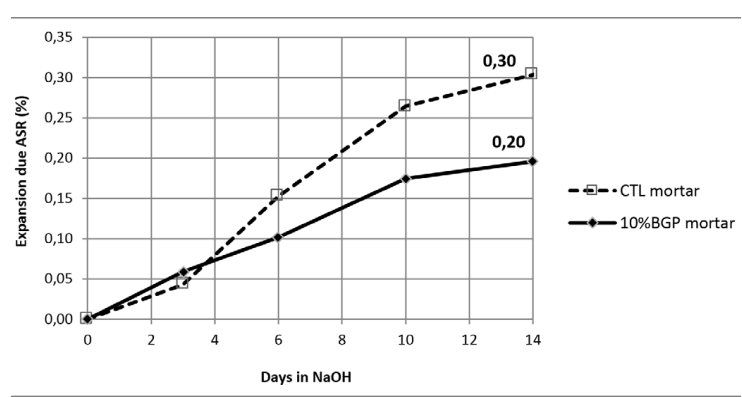

Figure 3. Expansion due to ASR.

Table 2. Grading requirements in ASTM C 1567 and grading for CEN sand used.

\begin{tabular}{cccc}
\hline $\begin{array}{c}\text { Grading requirements ASTM } \\
\text { C 1567 }\end{array}$ & \multicolumn{2}{c}{ CEN sand NP EN 196 -1 } \\
\hline $\begin{array}{c}\text { Retained on Sieve } \\
\text { Size }\end{array}$ & $\begin{array}{c}\text { Mass } \\
(\%)\end{array}$ & $\begin{array}{c}\text { Retained on } \\
\text { Sieve Size }\end{array}$ & $\begin{array}{c}\text { Mass } \\
\mathbf{( \% )}\end{array}$ \\
\hline 2,36 mm (No. 8) & 10 & $2,00 \mathrm{~mm}$ & 0 \\
1,18 mm (No. 16) & 25 & $1,60 \mathrm{~mm}$ & 7 \\
0,60 mm (No. 30) & 25 & $1,00 \mathrm{~mm}$ & 26 \\
0,30 mm (No. 50) & 25 & $0,50 \mathrm{~mm}$ & 34 \\
0,15 mm (No. 100) & 15 & $0,16 \mathrm{~mm}$ & 20 \\
\hline
\end{tabular}

\subsection{Self-compacting concrete mix-design, Mix proportions and Fresh properties}

When producing SCC, a key phase lies on the design of mix proportions so as to obtain adequate properties of fresh concrete. SCC in the fresh state must show filling ability, resistance to segregation and passing ability. To achieve these properties, the paste content (including mineral additions and the superplasticizer dosage) has to be increased and the coarse aggregate content must be reduced ${ }^{23}$. The "excess paste" should be the minimal quantity to create a "lubrificating" layer around the aggregate particles and reduce the inter-particle friction necessary to achieve self-compactability ${ }^{24}$. The mix-design method used is based on the Japanese SCC-designing method, consisting of a two level optimization method, one at mortar level and a second one at concrete level. This is described in more detail in $\mathrm{in}^{25,26}$. Mortar flow and funnel tests ${ }^{25,26}$ were carried out, at mortar level, to study the relation between both sands used (fine aggregate was a combination of two sands) along with paste volume and volumetric water/powder ratio. Adequate mortar properties for SCC are sufficiently well defined at this level ${ }^{25,26}$ and if target values are achieved, tests on concrete in the next stage, although essential, are reduced to a minimum. Final trials at concrete level of the designed concrete are necessary to quantify the amount of coarse aggregate, to adjust superplasticizer dosage (if necessary) and to confirm self-compactability ${ }^{25,26}$. To characterize fresh SCC, Slump-flow and V-funnel tests were used. The Slump-flow test, Figure 4, is used to evaluate deformation capacity, viscosity and also resistance to segregation of SCC by visual observation. This test enables recording final slump flow diameter $\left(\mathrm{D}_{\text {flow }}\right)$ and time necessary for concrete to reach a $50 \mathrm{~cm}$ diameter $\left(\mathrm{T}_{50}\right)^{27}$. The V-funnel test, Figure 5, is used to assess viscosity and passing ability of SCC, enabling

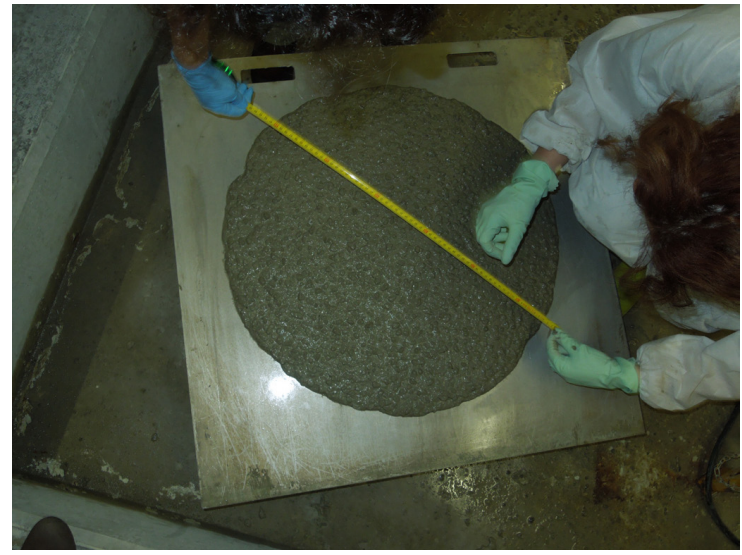

Figure 4. Slump-flow test.

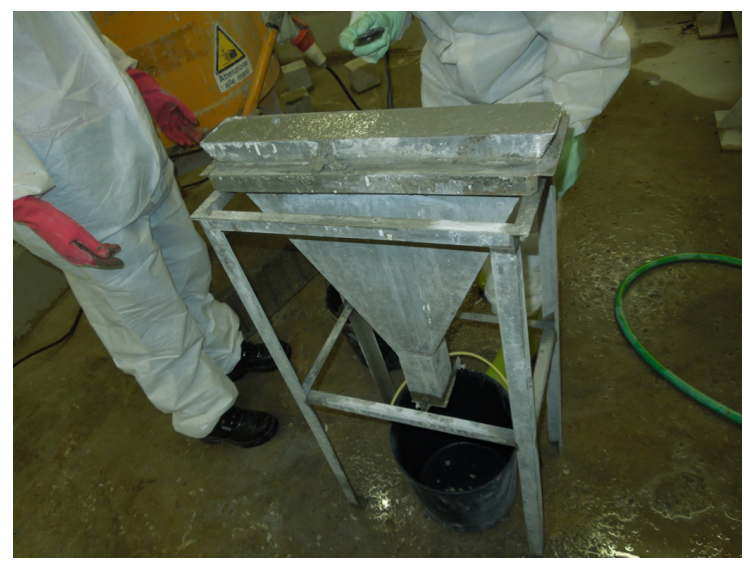

Figure 5. V-funnel test.

to record flow time $\left(\mathrm{T}_{\text {funnel }}\right)^{28}$. Mix proportions and results concerning fresh SCC testing can be seen in Table 3.

Several test specimens were produced as can be seen in Figure 6. After demoulding the following day, test specimens were cured at $20^{\circ} \mathrm{C} \pm 2^{\circ} \mathrm{C}$ and at relative humidity (RH) higher than $98 \%$, in a fog room, until testing.

\subsection{Tests on hardened SCC's}

\subsubsection{Compressive strength and Static modulus of elasticity}

Static modulus of elasticity testing, as well as, compressive strength were undertaken at 7,28 and 83 days, on specimens $150 \mathrm{~mm}$ diameter and approximately $300 \mathrm{~mm}$ length, according to DIN $1045-5^{29}$. Results are shown in Figure 7 and Figure 8, for CTL SCC and BGP SCC, respectively.

\subsubsection{Resistivity}

Electrical resistivity is an intrinsic property of the material which reports to the capability of cement paste to carry electric charge and it depends mainly on the hydration process (topography and nature and of the pore structure), changes in the composition of the pore solution and moisture and temperature conditions. Electrical resistivity was assessed by the two electrode technique on cylindrical specimens (50mm diameter and $150 \mathrm{~mm}$ height). Stainless steel plates, 
working as electrodes, were positioned against the dampened ends of each specimen ${ }^{30}$. Applying Ohm's Law, as shown in Eq. (1), the electrical resistance of the material is given by the relationship between the intensity of the applied current and the potential difference measured. Resistivity is obtained applying to the electrical resistance a geometric factor, which depends on the geometrical dimensions of the specimen and the electrodes used.

$R=\frac{V}{I}=\rho \cdot\left(\frac{L}{A}\right) \Rightarrow \rho=\frac{V \cdot A}{L \cdot I}$

where $\mathrm{R}$ is the electric resistance, $(\Omega)$; $\mathrm{I}$, current (Amp.); $\mathrm{V}$, voltage (Volts); $\rho$, electric resistivity $(\Omega \cdot \mathrm{m})$; L, length between electrodes $(\mathrm{m})$; and $\mathrm{A}\left(\mathrm{m}^{2}\right)$ the cross area of the test specimen through which current passes.

In fact, according to Andrade, stated by ${ }^{30}$, indications on the pore connectivity and therefore, on the concrete resistance to penetration of liquid or gas substances is provided by measuring the electrical resistivity of water saturated specimens. Therefore resistivity is a parameter which reports

Table 3. Mix proportions of SCC's and fresh properties.

\begin{tabular}{|c|c|c|}
\hline \multicolumn{3}{|c|}{ Mix proportions } \\
\hline & $\operatorname{CTL} \operatorname{SCC}\left(\mathrm{kg} / \mathrm{m}^{3}\right)$ & $\operatorname{BGP~SCC~}\left(\mathrm{kg} / \mathrm{m}^{3}\right)$ \\
\hline Cement & \multicolumn{2}{|c|}{400} \\
\hline Limestone Filler & 180 & 90 \\
\hline Glass Powder & - & 90 \\
\hline $\begin{array}{l}\text { Superplasticizer } \\
\text { (liquid) }\end{array}$ & \multicolumn{2}{|c|}{7.50} \\
\hline Coarse aggregate & \multicolumn{2}{|c|}{840} \\
\hline Sand 1 & \multicolumn{2}{|c|}{395} \\
\hline Sand 2 & \multicolumn{2}{|c|}{395} \\
\hline Water & \multicolumn{2}{|c|}{163.6} \\
\hline Water/binder $(\mathrm{w} / \mathrm{b})$ & \multicolumn{2}{|c|}{0.28} \\
\hline $\begin{array}{l}\text { Superplasticizer / } \\
\text { binder }(\mathrm{Sp} / \mathrm{b})\end{array}$ & \multicolumn{2}{|c|}{$1.32 \%$} \\
\hline \multicolumn{3}{|c|}{ Fresh Properties } \\
\hline $\mathrm{D}_{\text {flow }}(\mathrm{mm})$ & 600 & 670 \\
\hline $\mathrm{T}_{50}(\mathrm{~s})$ & 2,38 & 2,34 \\
\hline $\mathrm{T}_{\text {funnel }}(\mathrm{s})$ & 13,19 & 10,12 \\
\hline
\end{tabular}
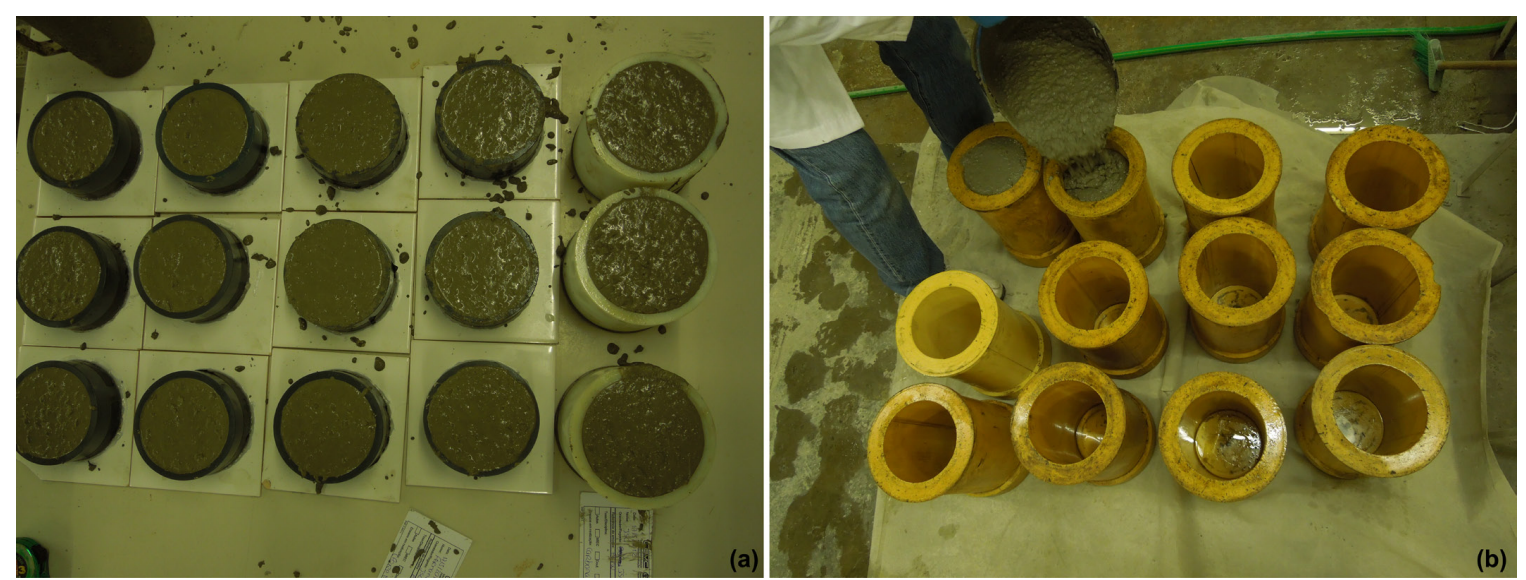

to the main key properties related to concrete durability. Andrade $^{31}$ also stated that the impact on total resistivity of the chemical composition of the pore solution is small, providing concrete remains alkaline. At high $\mathrm{pH}$ values, resistivity of the pore solution varies from 0.3 to $1.0 \Omega . \mathrm{m}$, which is comparatively very small considering that mortar resistivity after several days of hardening is in the range of a few dozen $\Omega . m$. Rajabipour et al. ${ }^{32}$ expressed that, for saturated cement paste specimens, pore connectivity is the single most important parameter governing overall conductivity. However some authors ${ }^{33}$ called attention to the fact that replacing Portland cement with supplementary cementing materials such as silica fume, fly ash and ground blast furnace may have a significant effect on electrical conductivity of the pore solution, depending on the alkali content of the supplementary cementing material, replacement level and age ${ }^{32}$.

Resistivity measurements $(\rho)$ were carried out at 7,28 and 83 days old concrete and at the same age compressive strength was analyzed. Since all the specimens were at the same moisture (saturated) and temperature conditions, resistivity can be used to compare the porous structure of the various specimens and therefore, constitute a measure of the amount and interconnectivity of the cementitious matrix pores. Results can be seen in Table 4.

\subsubsection{Chloride ion penetration}

Chloride permeability was evaluated by the CTH Rapid Method according to NT Build $492^{34}$. This non-steady state migration method is based on a theoretical relationship between diffusion and migration enabling, from an accelerated test, calculating the chloride diffusion coefficient $\left(\mathrm{D}_{\mathrm{ns}}\right)$.

Results obtained from the migration test carried out on 90 days old SCC specimens, applying a voltage of

Table 4. Resistivity results.

\begin{tabular}{crr}
\hline $\begin{array}{c}\text { Age of concrete (days)/ } \\
\text { Resistivity (k } \mathbf{\Omega . c m})\end{array}$ & CTL & BGP \\
\hline 7 & 5,36 & 5,31 \\
28 & 7,51 & 11,85 \\
83 & 10,00 & 26,90 \\
\hline
\end{tabular}

Figure 6. Test specimens. 


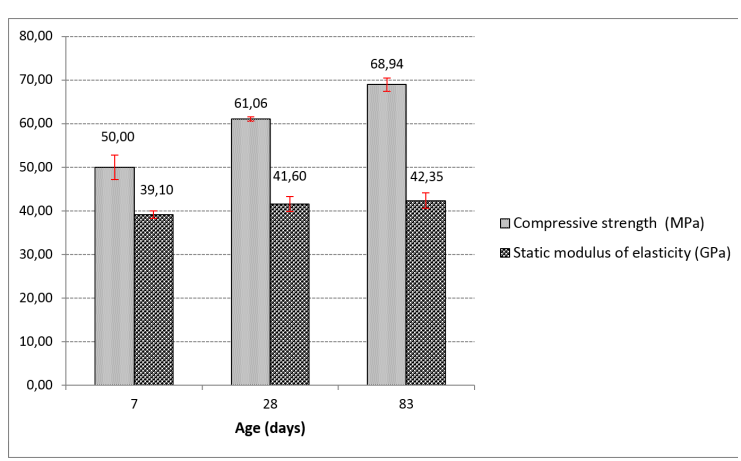

Figure 7. Results of compressive strength and modulus of elasticity for CTL SCC.

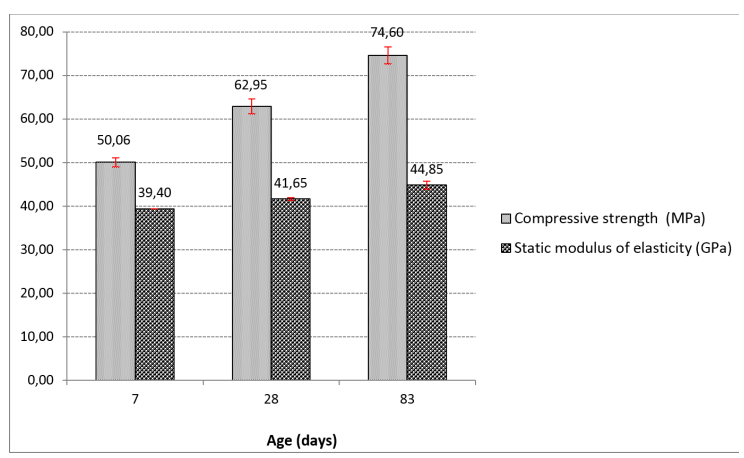

Figure 8. Results of compressive strength and modulus of elasticity of BGP SCC.

$30 \mathrm{~V}$ and 40V for 24 hours on CTL SCC and BGP SCC specimens respectively, can be seen in Figure 9.

The migration test also enables determining resistivity in saturated conditions, as the specimens must be fully saturated before the test. In fact, the electric current (I), measured in amperes, is defined as the amount of the electric charge (Q), measured in Coulombs, flowing through the cross section of the test specimen over time (t).

$I=\frac{Q}{T}$

According to eqt 1 , resistivity can then be calculated.

\subsubsection{Capillary water absorption}

Absorption by capillarity testing was undergone on two months old test specimens, approximately $50 \mathrm{~mm}$ diameter by $100 \mathrm{~mm}$ length, generally following procedure described in RILEM TC $116-\mathrm{PCD}^{35}$. After drying the samples y in a ventilated heater at $40^{\circ} \mathrm{C}$ until constant mass, test specimens were placed, moulded face downwards, in a shallow water bath. Water level was adjusted automatically so that the formwork (moulded) face was dipped to a constant depth of approximately $3 \mathrm{~mm}$. Water was drawn into the core by capillary forces during testing and weighed at time intervals up to 4,5 hours from the start of the test.

Absorption of water into concrete under capillary action is dependent on the square-root of time and may be modelled ${ }^{36}$ by the following equation:

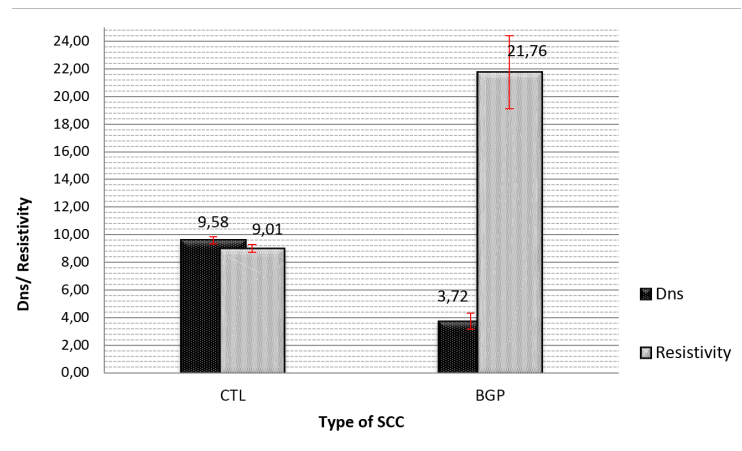

Figure 9. Chloride ion penetration test results.

$A=A_{0}+S t^{0,5}$

where $\mathrm{A}\left(\mathrm{mg} / \mathrm{mm}^{2}\right)$ is the water absorption by unit area of concrete surface since the moment the core was dipped in water, $\mathrm{S}$ is the sorptivity of the material, $\mathrm{t}$ is the elapsed time and $\mathrm{A}_{0}\left(\mathrm{mg} / \mathrm{mm}^{2}\right)$ is the water absorbed initially by pores in contact with water. The above equation was found to provide a very good fit to the data with correlation coefficients $(\mathrm{R})$ of over 0.988 (Figure 10). The average sorptivity value of each SCC type is 0.0310 and 0.0255 for CTL and BGP, respectively.

\subsubsection{Carbonation}

The procedure described in RILEM CPC- $18^{37}$ was followed to assess resistance to accelerated carbonation. Test specimens were exposed to $5 \pm 0.1 \%$ carbon dioxide, relative humidity $(\mathrm{RH})$ of $60 \pm 5 \%$ and temperature of $23 \pm 3^{\circ} \mathrm{C}$, in an accelerated carbonation chamber.

Carbonation depth was evaluated on three cylindrical test specimens for each SCC type, water cured at $20^{\circ} \mathrm{C}$ during 14 days followed by 14 days air curing $\left(20^{\circ} \mathrm{C}\right.$ and $\mathrm{HR}=50 \%$ ) and then exposed to $\mathrm{CO}_{2}$ during 28 days in the chamber. After splitting open each specimen, the surface was cleaned and sprayed with a phenolphthalein $\mathrm{pH}$ indicator. In the noncarbonated part of the specimen, corresponding to still highly alkaline concrete, a purple-red colour is obtained. In the carbonated part of the specimen, where alkalinity of mortar is reduced, coloration does not occur. Each value corresponds to the mean of eight measurements taken around the specimen of the freshly split and sprayed surface of the test specimen. Results can be seen in Figure 11.

\subsubsection{Oxygen permeability}

The underlying principle of oxygen permeability is the Hagen-Poiseuille relationship for laminar flow of a compressible fluid through a porous body with small capillaries under steady-state conditions. The relationship solved for the specific permeability coefficient $\mathrm{K}$ can be written as ${ }^{38}$ :

$k=\frac{2 Q p_{0} L \eta}{A\left(p^{2}-p_{a}^{2}\right)}$

where Q is the volume flow rate of the fluid $\left(\mathrm{m}^{3} / \mathrm{s}\right)$, A the cross-sectional area of the specimen $\left(\mathrm{m}^{2}\right)$, L the thickness of the specimen in the direction of flow $(\mathrm{m}), \eta$ the dynamic 


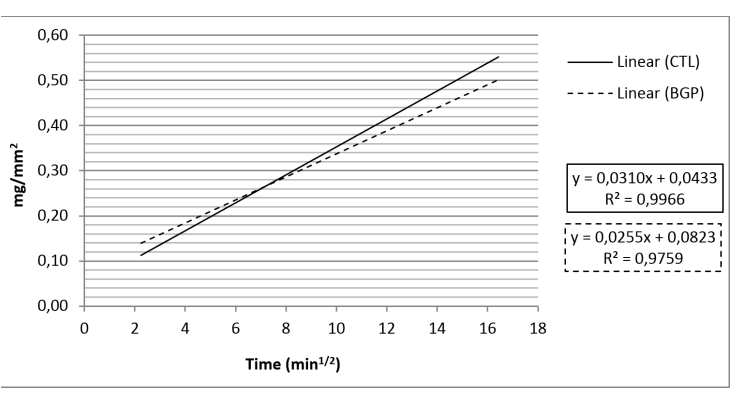

Figure 10. Linear regression for capillarity absorption versus square root of time, during $4 \mathrm{~h} 30 \mathrm{~min}$.

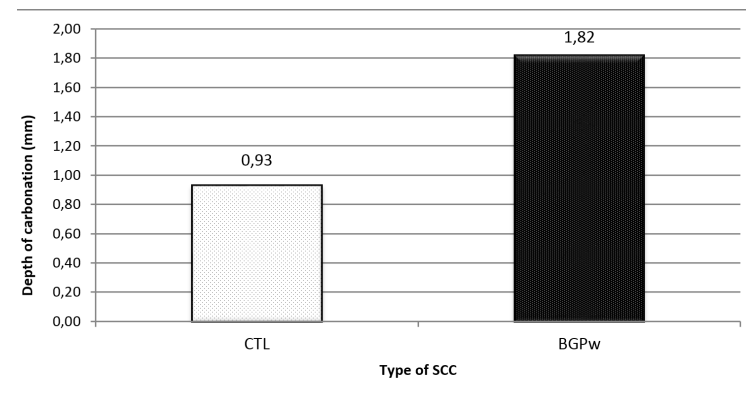

Figure 11. Carbonation depth results.

viscosity of the fluid at test temperature $\left(\mathrm{Ns} / \mathrm{m}^{2}\right), \mathrm{p}$ the inlet (absolute) pressure $\left(\mathrm{N} / \mathrm{m}^{2}\right), \mathrm{Pa}$ the outlet pressure assumed, in this test, to be equal to the atmospheric pressure $\left(\mathrm{N} / \mathrm{m}^{2}\right)$ and $\mathrm{P}_{0}$ the pressure at which the volume flow rate is determined, assumed, in this test, to be the same as the atmospheric pressure $\mathrm{Pa}\left(\mathrm{N} / \mathrm{m}^{2}\right)$.

For oxygen at a temperature of $20^{\circ} \mathrm{C}$, the dynamic viscosity may be taken at $2.02 \times 10^{-5} \mathrm{~N} \mathrm{~s} / \mathrm{m}^{2}$ and when the standard reference specimen of $150 \mathrm{~mm}$ diameter and $50 \mathrm{~mm}$ (corresponding to the present study) thickness is used the relationship is further simplified to:

$k_{\text {oxygen }}=\frac{1.14 \times 10^{-4} Q p_{a}}{\left(p^{2}-p_{a}^{2}\right)}$

Specimens were stored in the fog room at $20^{\circ} \mathrm{C}$ and relative humidity $(\mathrm{RH})$ of $100 \%$ for a period of 90 days. Then, they were transferred to the laboratory at $20^{\circ} \mathrm{C}$ and $\mathrm{RH}$ of $55 \%-65 \%$ for a period of 28 days. Specimens were supported on the cylindrical surface, ensuring a free movement of air around them. Testing was carried out on three specimens for each type of concrete and results showed that oxygen was unable to penetrate through the concrete.

\section{Discussion}

Analyzing these results makes it possible to evaluate the efficiency of BGP on SCC comparing mechanical and durability-related properties with conventional SCC (CTL).

Results obtained for ASR expansion respecting control mortar and according to ASTM 1567 (higher than $0.10 \%$ after 14 days in $\mathrm{NaOH}$ ) indicated potential deleterious expansion for this combination of cement and aggregate. However
ASR expansion for all specimens were significantly reduced by the use of $10 \%$ cement replacement by glass powder. It can be expected that for higher cement replacements greater expansion reduction will be obtained as stated by ${ }^{39}$. Hence ASR testing results confirmed that glass powder assisted in hindering expansion compared to control mortar, confirming assumptions by other authors ${ }^{16,17,40}$.

For Slump-flow, values ranging from 500 to $700 \mathrm{~mm}$ have been suggested for self-compacting concrete ${ }^{23}$. Segregation might occur for values above $700 \mathrm{~mm}$ and for slump-flow under $500 \mathrm{~mm}$, concrete might have insufficient flow to pass through highly congested reinforcement. The mixes in the present study conform to the above range 600-670 $\mathrm{mm}$. The slump flow time to reach diameter $(500 \mathrm{~mm})$ for all mixes was less than $6 \mathrm{~s}$. Results for flow times in the $\mathrm{V}$-funnel test were in the range of $10-13 \mathrm{~s}$. As per EFNARC ${ }^{23}$, time ranging from 6 to $12 \mathrm{~s}$ is considered adequate for SCC. V-funnel measurements of the BGP mix did not reach the lower limit; however, concrete filled the moulds by its own weight. In addition to the above properties, visual inspection of fresh concrete did not indicate any segregation or considerable bleeding in any of the mixtures during slump flow testing. According to NP EN 1350-8 ${ }^{27}$, CTL SCC can be classified as SF1 and BGP SCC as SF2. In terms of viscosity and filling ability ${ }^{28}$, both types of SCC correspond to VF2 class.

Regarding mechanical properties, all mixes showed strength gain beyond 28 days but at 83 days BGP SCC attained higher values, the control mixture reaching $69 \mathrm{MPa}$ and BGP, $74 \mathrm{MPa}$. A similar trend was observed for the modulus of elasticity; in this case influence of glass powder was not so pronounced. Differences between strength of both mixes resulted from the pozzolanic nature of glass powder and its behaviour with time and also by the fact that fineness of glass powder enhances pozzolanic properties and particle packing density ${ }^{40}$. As glass powder is a amorphous pozzolanic material, when it is used in concrete as cement replacement, it can contribute to the formation of hydration products and $\mathrm{C}-\mathrm{S}-\mathrm{H}$ gel. According to Shi et $\mathrm{al}^{41}$ finely ground glass powders exhibit very high pozzolanic activity. The finer the glass powder is, the higher its pozzolanic activity ${ }^{41,42}$.

Electrical resistivity of concrete was in the range of 5.36-10.0 and 5.31-26.9 kohm.cm for BGP and CTL concrete, respectively, between 7 and 80 days old. The lowest electrical resistivity value was measured for control concrete. In accordance with some authors ${ }^{43,44}$, the use of mineral additions increases electrical resistivity of SCC when compared to that of reference concrete.

Resistance to chloride ion penetration was enhanced significantly in the presence of glass powder. Coefficients of chloride diffusion for CTL specimens and BGP specimens were 9.58 and $3.7210^{-12} \mathrm{~cm}^{2} / \mathrm{s}$, respectively. According to $^{45}$, as can be seen in Table 5, CTL SCC presented high resistance do chloride and BGP SCC, very high resistance.

Sorptivity is the rate of water absorbed into the concrete pores by capillary suction. The Sorptivity values of mixes with glass are lower than those of the control mix. This can be attributed to the surplus of $\mathrm{C}-\mathrm{S}-\mathrm{H}$ gel formed during pozzolanic reaction initiated by the presence of glass powder, which improved homogeneity of the microstructure 
Table 5. Concrete classification according to chloride penetration test result.

\begin{tabular}{cc}
\hline \multicolumn{2}{c}{$\begin{array}{c}\text { Resistance do chloride } \\
\text { chloride migration coefficient [49] }\end{array}$} \\
\hline Low & Dns $\geq 15^{*} 10^{-12} \mathrm{~m}^{2} / \mathrm{s}$ \\
Moderate & $10^{*} 10^{-12}<$ Dns $<15^{*} 10^{-12} \mathrm{~m}^{2} / \mathrm{s}$ \\
High & $5^{*} 10^{-12}<$ Dns $<10^{*} 10^{-12} \mathrm{~m}^{2} / \mathrm{s}$ \\
Very high & $2,5^{*} 10^{-12}<$ Dns $<5^{*} 10^{-12} \mathrm{~m}^{2} / \mathrm{s}$ \\
Extremely high & Dns $\leq 2,5^{*} 10^{-12} \mathrm{~m}^{2} / \mathrm{s}$ \\
\hline
\end{tabular}

and refined its pore network, thus resulting in lower open porosity and sorptivity.

Carbonation depth for glass containing SCC was greater than CTL SCC. It is consistent with the trend observed in concrete for various pozzolanic materials and probably due to $\mathrm{CH}$ reduction. Incorporating BGP both contribute to $\mathrm{CH}$ reduction, which reduces $\mathrm{pH}$ of the mix.

According to reported results regarding oxygen permeability ${ }^{46}$, it was observed that oxygen was unable to penetrate through the concrete. When the amount of cement and filler is increased, as in SCC mix design, there is a significant decrease of the apparent gas permeability induced by a lower porosity because of the lower W/C ratio $^{47}$.

\section{References}

1. Shah SP, Akkaya Y, Bui VK. Innovations in microstructure, processing and properties. In: Dhir R, Hewlett PC, Csetenyi $\mathrm{LJ}$, editors. Innovations and developments in concrete materials and construction. Proceedings of the International Conference Challenges of concrete construction, 1999 Sept 9-11. Scotland, UK: University of Dundee.

2. Okamura H, Ouchi M. Self compacting concrete. Journal of Advanced Concrete Technology. 2003;1(1):5-15.

3. Nunes S, Figueiras H, Milheiro Oliveira P, Coutinho JS, Figueiras J. A methodology to assess robustness of SCC mixtures. Cement and Concrete Research. 2006;36(12):2115-2122.

4. Tittarelli F, Moriconi G. Use of GRP industrial by-products in cement based composites. Cement \& Concrete Composites. 2010;32:219-225.

5. Liu M. Incorporating ground glass in self-compacting concrete. Construction and Building Materials. 2011;25:919-925.

6. Ye G, Liu X, De Schutter G, Poppe AM, Taerwe. Influence of limestone powder used as filler in SCC on hydration and microstructure of cement pastes. Cement and Concrete Composites. 2007;29(2):94-102.

7. Poppe AM, Schutter GD. Cement hydration in the presence of high filler contents. Cement and Concrete Composites. 2005;35(12):2290-2299.

8. Assie S, Escadeillas G, Waller V. Estimates of self-compacting concrete potential durability. Construction and Building Materials. 2007;21(10):1909-1917.

9. Unal O, Topcu IB, Uygunoglu T. Use of marble dust in self compacting concrete. In: V Symposium MERSEMO 2006 on marble and natural stone. Afyon, Turkey; 2006. p. 413-20.

10. Felekoglu B, Tosun K, Baradan B, Altun A, Uyulgan B. The effect of fly ash and limestone fillers on the viscosity and compressive

\section{Conclusions}

This study aimed to evaluate use of waste glass powder in powder type SCC. It could be concluded that waste glass powder can be used successfully in SCC further improving chloride penetration and water absorption by capillarity, maintaining strength levels.

Although soda lime glass presents a high alkali content, use of ground waste glass as cement replacement in mortar, improved resistance to ASR.

These results corroborate the pozzolanic nature of glass powder and its behaviour with time. Although glass powder is a little coarser than cement, it still brings advantages when incorporated in cement.

\section{Acknowledgments}

This work was financed by FEDER funds under the Operational Program Factors of Competiveness - COMPETE - and by National Funds under FCT Foundation for Science and Technology through project PTDC/ECM/098117/2008 Additions from waste materials for sustainable structural concrete and through project PTDC/ECM/122446/2010 - Engineered high performance fibre reinforced concrete materials: design, characterization and quality control.

The authors also thank Fernando Augusto Sales for the glass powder used in this work.

strength of self-compacting repair mortars. Construction and Building Materials. 2006;36(9):1719-1726.

11. Turkmen, I. Influence of different curing conditions on the physical and mechanical properties of concretes with admixtures of silica fume and blast furnace slag . Materials Letters. 2003;57(29):4560-4569

12. Sahmaran M. Christianto HA, Yaman IO. The effect of chemical admixtures and mineral additives on the properties of self-compacting mortars. Cement and Concrete Composites. 2006;28(5):432-440.

13. Matos AM, Sousa-Coutinho J. Durability of mortar using waste glass powder as cement replacement. Construction and Building Materials. 2012;36:205-215.

14. ASTM International. Standard specification for coal fly ash and raw or calcined natural pozzolan for use in concrete. Philadelphia: ASTM; 2012. (ASTM C 618 - 12).

15. Schwarz N, Cam H, Neithalath N. Influence of a fine glass powder on the durability characteristics of concrete and its comparison to fly ash. Cement and Concrete Composites. 2008;30(6):486-496.

16. Schwarz N, Cam H, Neithalath N. Influence of a fine glass powder on the durability characteristics of concrete and its comparison to fly ash. Cement and Concrete Composites. 2008;30(6):486-96.

17. Saccani A, Bignozzi MC. ASR expansion behavior of recycled glass fine aggregates in concrete. Cement and Concrete Research. 2010;40:531-6.

18. Rossomagina AS, Saulin DV, Puzanov IS. Prevention of alkalisilica reaction in glass aggregate concrete. Russia: Perm State Technical University; 2004. http://www.allbeton.ru/upload/ mediawiki/e85/prevention-of-alkali_silica-reaction-in-glassaggregate-concrete-_rossomagina_.pdf. 
19. Kim J, Yi CK, Zi G. Waste glass sludge as a partial cement replacement in mortar. Construction and Building Materials. 2015;75(30):242-246.

20. Kim J, Moon JH, Sim JW, Sim J, Lee HG, et al. Durability properties of a concrete with waste glass sludge exposed to freeze-and-thaw condition and de-icing salt. Construction and Building Materials. 2014;66:398-402.

21. ASTM International. ASTM C1567-11. Standard test method for determining the potential alkali silica reactivity of combinations of cementitious materials and aggregate (Accelerated Mortar Bar Method). Philadelphia : ASTM International; 2011. http:// infostore.saiglobal.com/store/details.aspx?ProductID=1489520.

22. EN 196-1 Methods of testing cement - Part 1: Determination of strength. Lisbon, Portugal: IPQ; 2010.

23. Experts for Specialised Construction and Concrete Systems. EFNARC. The European Guidelines for self-compacting concrete: specification, production and use. EFNARC; 2005.

24. Walraven J. Self-compacting concrete: challenge for designer and researcher. In: Shah SP, editor. Second North American conference on the design and use of self-consolidating concrete. Fourth International RILEM symposium on self-compacting concrete. Chicago: 2005. p. 431-445.

25. Nunes S. Experimental study and numerical modelling of selfcompacting concrete. In: Walraven J, Blaauwendraad J, Scarpas $\mathrm{T}$, Snidjer B, editors. 5th International PhD symposium in Civil Engineering. Delft, The Netherlands; 2004. p. 857-65.

26. Nunes S, Figueiras H, Sousa Coutinho J, Figueiras J. Método para definição da composição de betão auto-compactável. E-MatRevista de Ciência e Tecnologia de Materiais de construção Civil. 2005;2(1):1-11.

27. NP EN 12350-8:2010. Testing fresh concrete. Part 8: Selfcompacting concrete - Slump-flow test. Lisbon, Portugal: IPQ; 2010 .

28. NP EN 12350-9:2010. Testing fresh concrete. Part 9: Selfcompacting concrete - Vfunnel test. Lisbon, Portugal: IPQ; 2010.

29. Deutsche Norm. DIN 1048-1: Testing concrete. Testing of hardened concrete specimens prepared in moulds. Berlin; 1991.

30. Figueiras H, Nunes S, Sousa-Coutinho J, Andrade C. Linking fresh and durability properties of paste to SCC mortar. Cement and Concrete Composites, 2014;45:209-226.

31. Andrade C. Calculation of initiation and propagation periods of service life of reinforcements by using the electrical resistivity. In: Weiss J, Kovler K, Marchand J, Mindess S. editors. First International RILEM Symposium on Advances in Concrete Through Science and Engineering: A Tribute to Arnon. Evanston: RILEM Publications SARL; 2004.

32. Rajabipour F, Weiss J. Electrical conductivity of drying cement paste. Materials and Structures. 2007;40:1143-1160.
33. Shi C, Stegemann JA, Caldwell RJ. Effect of supplementary cementing materials on the specific conductivity of pore solution and its implications on the rapid chloride permeability test (AASHTO T277 and ASTM C1202) results. ACI Materials Journal. 1998; 95(4):389-393.

34. Nordtest Method - NT Build 492. Concrete, mortar and cement-based repair materials: chloride migration coefficient from non-steady-state migration experiments. Finland: Nordic Council of Ministers; 1999. http://210.42.35.80/G2S/eWebEd itor/uploadfile/20110819235419966.pdf

35. RILEM. RILEM TC 116-PCD - Permeability of Concrete as a Criterion of its Durability. Recommendations. Materials and Structures. 2009;32:174-179.

36. Hall C. Water sorptivity of mortar and concretes - A review. Magazine of Concrete Research. 1989;41(147):51-61.

37. RILEM. RILEM CPC-18 Measurement of hardened concrete carbonation depth. Material and Structures. 1984;102.

38. Kollek JJ. The determination of the permeability of concrete to oxygen by the Cembureau method: a recommendation. Materials and Structures. 1989;22:225-230.

39. Nunes S, Matos AM, Duarte T, Figueiras H, Sousa-Coutinho J. Mixture design of self-compacting glass mortar. Cement and Concrete Composites. 2013;43:1-11. Doi:10.1016/ j;cemconcomp.2013.05.009

40. Taha B, Nounu G. Using lithium nitrate and pozzolanic glass powder in concrete as ASR suppressors. Cement and Concrete Composites. 2008;30(6):497-505.

41. Shi $\mathrm{C}, \mathrm{Wu} \mathrm{Y}$, Riefler $\mathrm{C}$, Wang $\mathrm{H}$. Characteristics and pozzolanic reactivity of glass powders. Cement and Concrete Research. 2005;35(5):987-993.

42. Shaoa Y, Lefort T, Moras S, Rodriguez D. Studies on concrete containing ground waste glass. Cement and Concrete Research. 2000;30(1):91-100.91-100. doi:10.1016/S0008-8846(99)00213-6

43. Madandoust R, Mousavi SY. Fresh and hardened properties of self-compacting concrete containing metakaolin. Construction and Building Materials. 2012;35: 752-760.

44. Gesoğlua M, Güneyisia E, Özbayb E. Properties of selfcompacting concretes made with binary, ternary, and quaternary cementitious blends of fly ash, blast furnace slag, and silica fume. Construction and Building Materials. 2009;23(5): 1847-1854.

45. Nilsson L, Ngo MH, Gjorv OE. High-performance repair materials for concrete structures in the port of Gothenburg. In: Second International Conference on Concrete Under Severe Conditions Environment and Loading. Norway; 1998. p. 11931198.

46. Zhu W, Bartos PJ. Permeation properties of self-compacting concrete. Cement and Concrete Research. 2003;33(6):921-926.

47. Boel V, Audenaert K, Schutter G. Gas permeability and capillary porosity of self-compacting concrete. Materials and Structures. 2008;41(7):1283-1290. 